\title{
Oxidative Stability of Baru (Dipteryx alata Vogel) Oil Monitored by Fluorescence and Absorption Spectroscopy
}

\author{
Vanessa D. Silva, ${ }^{1}$ José N. Conceição, ${ }^{1}$ Ivan P. Oliveira, ${ }^{1}$ \\ Caroline H. Lescano, ${ }^{1}$ Rozanna M. Muzzi, ${ }^{1}$ Omar P. S. Filho, ${ }^{2}$ Edemilson C. Conceição, ${ }^{2}$ \\ Gleison A. Casagrande, ${ }^{3}$ and Anderson R. L. Caires ${ }^{1}$ \\ ${ }^{1}$ Grupo de Óptica Aplicada, Universidade Federal da Grande Dourados, CP 533, 79804-970 Dourados, MS, Brazil \\ ${ }^{2}$ Faculdade de Farmácia, Universidade Federal de Goiás, CP 131, 74001-970 Goiânia, GO, Brazil \\ ${ }^{3}$ Instituto de Química, Universidade Federal de Mato Grosso do Sul, CP 549, 79074-460 Campo Grande, MS, Brazil
}

Correspondence should be addressed to Anderson R. L. Caires; andersoncaires@ufgd.edu.br

Received 29 October 2014; Revised 11 February 2015; Accepted 19 February 2015

Academic Editor: Austin Nevin

Copyright (C) 2015 Vanessa D. Silva et al. This is an open access article distributed under the Creative Commons Attribution License, which permits unrestricted use, distribution, and reproduction in any medium, provided the original work is properly cited.

Baru (Dipteryx alata Vogel) is a native fruit of the Brazilian savanna that provides a nutritive oil, which also has medicinal properties. Baru fruits were collected in central-western Brazil, and the oil was obtained by pressing the seeds. The Baru oil was heated at $110^{\circ} \mathrm{C}$ for $24 \mathrm{~h}$, and its oxidative stability was investigated by using fluorescence and absorption spectroscopy. The data showed that both absorption and fluorescence were able to precisely monitor the oil degradation induced by the thermooxidative process. The results revealed a rapid growth of the primary compounds generation in the first 16 hours of degradation. Significant amounts of secondary compounds began to be generated after 14 hours.

\section{Introduction}

Baru (Dipteryx alata Vogel), known also as cumbaru, cumaru, barujo, coco-feijão, cumarurana, emburena-brava, feijãococo, and pau-cumaru [1], is a native tree of the Brazilian savanna. The pulp from its fruit is used to make jams and jellies, and the nut is also edible, with good food value, and rich in oil with medicinal properties, specially used as antirheumatic agent [2]. Previous studies showed that the high nutritional value of Baru nuts stems from their high content of lipids, protein, fiber, and some essential minerals such as potassium, phosphorus, magnesium, calcium, iron, and zinc $[3,4]$. Takemoto and collaborators found that Baru seed oil is highly unsaturated due to the predominance of oleic and linoleic acids and its $\alpha$-tocopherol content $[3,5]$. Based on these chemical properties, Baru oil can be used not only for food, but also in the cosmetics and oleochemical industries.

Recently, Baru oil was also proposed for use as an alternative source to produce biofuels, due to its physical and chemical characteristics [6]. Batista and coworkers, by analyzing the peroxide number, iodine number, kinematic viscosity, water content, relative density, saponification number, and refractive index, confirmed the high quality of Baru oil for use as a raw material for biodiesel production [6].

The chemical and physical characteristics of the raw material used in the preparation of biofuel are important, as biodiesel quality is totally dependent on the physical and chemical properties of the oil. For instance, the oxidative stability of the vegetable oil is one of the most important parameters governing the final quality of the biodiesel $[7$, 8]. The oxidative stability of biodiesel can be affected by many factors such as exposure to UV light, heavy-metal contamination, and temperature changes [9-11]. Although a recent study analyzed the thermal stability of the Baru oil by thermogravimetry [5], to the best of our knowledge, the thermooxidative stability of this oil has not yet been evaluated by using optical techniques.

In recent years, optical methods have been used as analytical tools for characterizing and monitoring the stability and quality of vegetable oils, biodiesels, and biofuel blends [12-15]. Dantas and colleagues demonstrated that 
the UV-Vis absorption technique can be used to precisely determine the oxidative stability of vegetable oils [9]. They showed that thermodegradation of the oil can be monitored by means of the absorption peaks at around 232 and $270 \mathrm{~nm}$, because light absorption in this wavelength region is strongly affected by the primary and secondary oxidation products generated during the thermooxidation process [9]. Additionally, Cheikhousman and coworkers have shown that fluorescence spectroscopy can be used to investigate the quality of vegetable oil [12]. Fluorescence spectroscopy was successfully used to monitor the deterioration of extra virgin olive oil during heating [12].

As Baru oil has good potential for use in the food, pharmaceutical, cosmetic, and biodiesel industries, where thermal stability is an essential parameter for the final product quality, the present study analyzed the thermooxidative stability of this oil by using UV-Vis absorption and fluorescence spectroscopy measurements.

\section{Material and Methods}

Baru fruits were collected in central-western Brazil $\left(16^{\circ} 42^{\prime} 50^{\prime \prime} \mathrm{S} 49^{\circ} 00^{\prime} 07^{\prime \prime} \mathrm{W}\right)$, and the seeds were extracted from the fruits. Baru oil was obtained by pressing the seeds in a minipress compression machine (Ecirtec). After extraction, the oil was stored in an airtight container, in a freezer at $-10^{\circ} \mathrm{C}$.

The analysis of the composition of fatty acids was performed by gas chromatography according to the AOCS method [16], using a gas chromatographer (Agilent 68650 series GC system), equipped with capillary column DB23 (50\% cyanopropil-methylpolysiloxane $60 \mathrm{~m} \times 0.25 \mathrm{~mm}$ i.d., $0.25 \mu \mathrm{m}$ of film) and flame ionization detector (FID). The chromatographic conditions were as follows: initial temperature at $110^{\circ} \mathrm{C} / 5 \mathrm{~min}$; heating at $110-215^{\circ} \mathrm{C}$ on a scale of $5^{\circ} \mathrm{C} / 5 \mathrm{~min}$ and at $215^{\circ} \mathrm{C}$ for $24 \mathrm{~min}$; carrier gas, helium (flow of $1 \mu \mathrm{L} / \mathrm{min}$ ); injector's temperature, $250^{\circ} \mathrm{C}$; detector's temperature, $280^{\circ} \mathrm{C}$; and injection volume, $1 \mu \mathrm{L}$. The identification of the fatty acids was conducted by comparing the retention time of the fatty acids from the sample and the standards. The quantification was conducted by area normalization, and the results were expressed in $\mathrm{g} / 100 \mathrm{~g}$ of the sample.

For the thermodegradation process, the oil sample, divided into 9 aliquots of $5 \mathrm{~mL}$, was placed in an oven with air circulation (Sterilifer SXCR42) and heated at $110^{\circ} \mathrm{C}$. The oil aliquots were removed after $2,4,6,8,10,12,14,16$, and $24 \mathrm{~h}$.

The UV-Vis absorption was characterized with the use of a bench spectrophotometer (Varian Cary-50) and a quartz cell with $10 \mathrm{~mm}$ path length at $22^{\circ} \mathrm{C}$. The oil was diluted in hexane (Vetec > 99\%) and the absorption was measured between 225 and $750 \mathrm{~nm}$. The absorption bands with maximum absorption at around 475 and 270 and $232 \mathrm{~nm}$ were analyzed from diluted samples at concentrations of $50 \%(\mathrm{w} / \mathrm{v})$ for the absorption at $475 \mathrm{~nm}$ and $0.15 \%(\mathrm{w} / \mathrm{v})$ in the case of the absorptions at 270 and $232 \mathrm{~nm}$.

Fluorescence spectra were collected from diluted samples at a concentration of $50 \%(\mathrm{w} / \mathrm{v})$ in the $450-750 \mathrm{~nm}$ range when excited at $405 \mathrm{~nm}$. The fluorescence signal was obtained
TABLE 1: Composition of fatty acids in the oil from Dipteryx alata Vogel oil. Values are expressed as a percentage in relation to total fatty acids quantified.

\begin{tabular}{|c|c|c|}
\hline \multicolumn{2}{|l|}{ Fatty acids (\%) } & \multirow{2}{*}{$\begin{array}{c}\text { Values } \\
0.06 \pm 0.01^{\mathrm{a}}\end{array}$} \\
\hline Myristic & C 14:0 & \\
\hline Palmitic & C 16:0 & $6.37 \pm 0.01$ \\
\hline Palmitoleic & C $16: 1$ & $0.07 \pm 0.01^{\mathrm{a}}$ \\
\hline Margaric & C 17:0 & $0.08 \pm 0.01^{\mathrm{a}}$ \\
\hline Heptadecenoic & C 17:1 & $0.06 \pm 0.02^{\mathrm{a}}$ \\
\hline Stearic & C 18:0 & $4.95 \pm 0.01$ \\
\hline Oleic & C $18: 1$ & $47.86 \pm 0.05$ \\
\hline Linoleic & C $18: 2$ & $28.91 \pm 0.00$ \\
\hline Linolenic & C $18: 3$ & $0.18 \pm 0.00$ \\
\hline Arachidic & C 20:0 & $1.29 \pm 0.00$ \\
\hline Eicosenoic & C 20:1 & $2.46 \pm 0.01$ \\
\hline Behenic & C 22:0 & $3.19 \pm 0.02$ \\
\hline Erucic & C $22: 1$ & $0.26 \pm 0.04$ \\
\hline Lignoceric & C 24:0 & $4.26 \pm 0.04$ \\
\hline & & $20.20 \pm 0.10$ \\
\hline$\sum$ Mon & & $50.71 \pm 0.13$ \\
\hline$\sum$ Poly & & $29.09 \pm 0.00$ \\
\hline
\end{tabular}

Equal letters on the column represent values which do not differ significantly $(P<0.05)$. To compare the means, ANOVA followed by Tukey test was used. The values are mean \pm standard deviations of duplicate analysis.

by using a portable fluorimeter (MM Optics) containing a laser as excitation source, a monochromator for emission collection, a Y-type optical fiber to collect the light, and a laptop to process the data. The spectra were collected by using front-face geometry and all measurements were carried out using a quartz cell with $10 \mathrm{~mm}$ path length, with four polished faces, at $22^{\circ} \mathrm{C}$.

\section{Results and Discussion}

Table 1 presents the composition of fatty acids of Baru oil. As expected, a high degree of unsaturation was determined in which oleic (C 18:1) and linoleic (C 18:2) acids were the most predominant fatty acids, representing approximately $77 \%$ of the total composition.

Figure 1 shows the absorption spectrum of the Baru oil between 225 and $550 \mathrm{~nm}$ when diluted in hexane. To better observe the absorption bands, appropriate dilutions were chosen in the ranges of $225-350 \mathrm{~nm}(0.15 \% \mathrm{w} / \mathrm{v})$ and $350-$ $550 \mathrm{~nm}(50 \% \mathrm{w} / \mathrm{v})$. In general, the molecular absorption of vegetable oils between 225 and $350 \mathrm{~nm}$ is mainly attributed to tocopherols, although the contribution of some fatty acids should not be ruled out [17]. Chlorophylls as well as carotenoids may be absorbed in the 350-550 range [17]; however, in analyzing the diluted sample, our data revealed that carotenoids are the main compounds responsible for the observed absorption between 350 and $550 \mathrm{~nm}$, as demonstrated in Figure 2 where $\beta$-carotene absorption spectrum is shown. In fact, it is well known that the absorption of light 


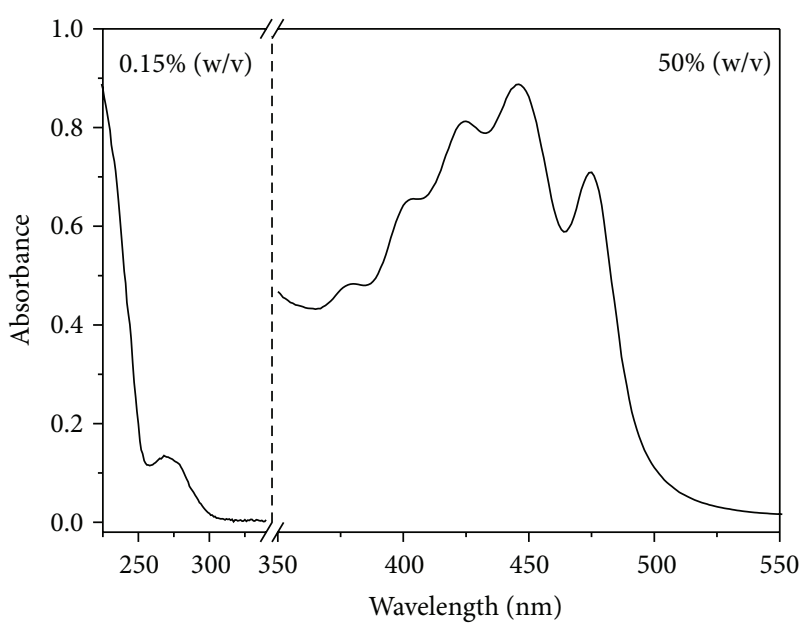

FIgURE 1: Baru oil absorbance spectrum collected from a diluted sample. The oil was diluted in hexane, and a more concentrated sample was used to better determine the absorption bands in the $350-550 \mathrm{~nm}$ range (see text).

by carotenoids is due to the presence of conjugated carboncarbon double bonds and that a typical absorbance spectrum of a carotenoid contains three bands in the blue region of the optical spectrum (400-500 nm) where the maxima of which are functions of the chromophore lengths [18] as carotenoids consist of a sequence of alternating carbon double and single bonds ( $\mathrm{C}=\mathrm{C}$ and $\mathrm{C}-\mathrm{C}$ bonds, resp.), with the outer electron free to move along the chain [19]. Additionally, it is well established that these absorption bands, which give carotenoids their color, are due to the $1 \mathrm{~A}_{\mathrm{g}}{ }^{-} \rightarrow 1 \mathrm{~B}_{\mathrm{u}}^{+}$transition [20].

As previously mentioned, the thermodegradation of vegetable oils can be monitored by analyzing the absorption peaks at around 232 and $270 \mathrm{~nm}$, because the absorptions in these wavelength regions are strongly affected by the primary and secondary oxidation products generated during the thermooxidation process [9]. Figure 3 shows the absorption at 232 and $270 \mathrm{~nm}$ as a function of the degradation time.

The observed increase in absorption at $232 \mathrm{~nm}$ is due to compounds generated during the primary degradation of the oil, conjugated dienes, which show $\pi-\pi^{*}$ transitions [9]. The changes in absorption at $270 \mathrm{~nm}$ are related to the formation of secondary compounds of the degradation, such as diketones and unsaturated ketones, the absorption of which is also due to the $\pi-\pi^{*}$ transitions $[9,11]$. The results clearly show that the generation of primary compounds increased rapidly in the first 16 hours. In contrast, the generation of secondary compounds began to be significant after 14 hours of thermodegradation. The relation between the primary and secondary compounds during the degradation as a function of the heating time can be better visualized from the absorption ratio at 232 to $270 \mathrm{~nm}$, as shown in Figure 4.

Although several studies have shown that the increase in absorption at 232 and $270 \mathrm{~nm}$ can be used to monitor oil degradation induced by thermooxidation, as was also demonstrated here, the present data indicate that oil
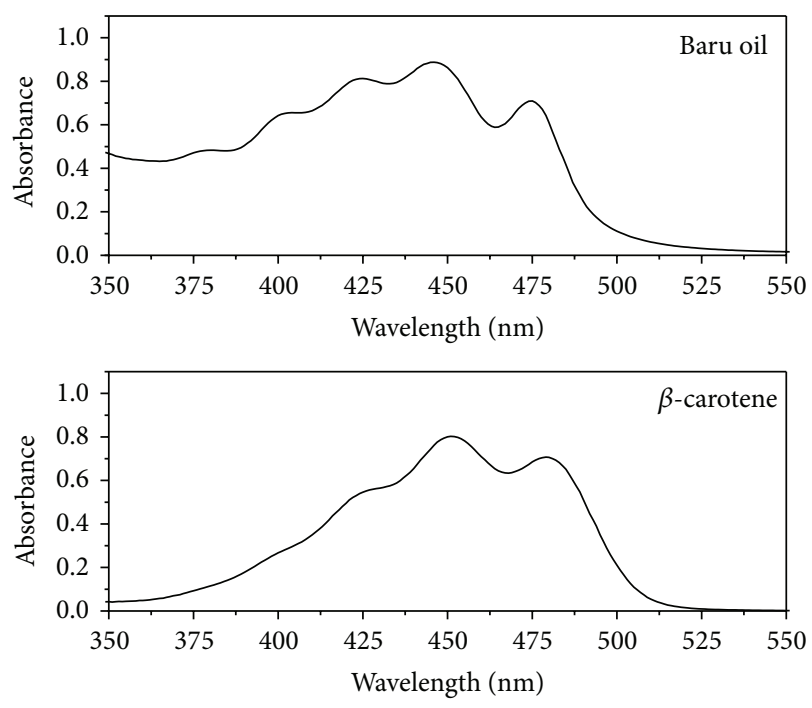

Figure 2: Baru oil and $\beta$-carotene absorbance between 350 and $550 \mathrm{~nm}$. All samples were diluted in hexane.

absorption at around $475 \mathrm{~nm}$ can also be effectively used to monitor oil degradation. As shown in Figure 5, the absorption bands between 350 and $550 \mathrm{~nm}$ decrease as a function of the degradation time. A linear decrease in absorption at $475 \mathrm{~nm}$ was observed during the first 8 hours, with a slope of -0.069 and a correlation coefficient of 0.989 , and almost no absorption was detected after that. This suggests that carotenoids are almost totally degraded in the first hours of thermal treatment. This is possible because carotenoids are highly unsaturated molecules with many conjugated double bonds, making them susceptible to degradation [21, 22]. Henry and coworkers have demonstrated rapid thermodegradation (thermooxidation) of all-trans $\beta$-carotene, 9-cis $\beta$-carotene, lycopene, and lutein in safflower seed oil heated at 75,85 , and $95^{\circ} \mathrm{C}[21]$. They also found that only trace amounts of carotenoids remained after 5,12 , and $24 \mathrm{~h}$ when the oil was heated at 95,85 , and $75^{\circ} \mathrm{C}$, respectively.

In addition to the absorption analyses, fluorescence spectroscopy was applied to characterize the emissions from the Baru oil, as well as to investigate the potential of the fluorescence technique as an alternative method to evaluate the oil degradation. Figure 6(a) shows the typical emission spectrum of Baru oil when excited at $405 \mathrm{~nm}$. The fluorescence data revealed that $\beta$-carotene and chlorophyll are the main fluorophores responsible for the emission between 450 and $750 \mathrm{~nm}$, when excited at $405 \mathrm{~nm}$, as presented in Figure 6(b) $[17,18]$. In fact, it is well know that different oil constituents such as $\beta$-carotene, $\alpha$-tocopherol, oleic acid, and chlorophyll may fluoresce in this range when excited by blue radiation (at around $450 \mathrm{~nm}$ ) [18, 21].

Our results also revealed that the overall fluorescence signal between 550 and $750 \mathrm{~nm}$ was reduced in response to the thermodegradation. As presented in Figure 7, the observed decreases in fluorescence at 568 and $675 \mathrm{~nm}$ over the degradation period are mainly attributed to thermodegradation of the carotenoids and chlorophylls, respectively. 

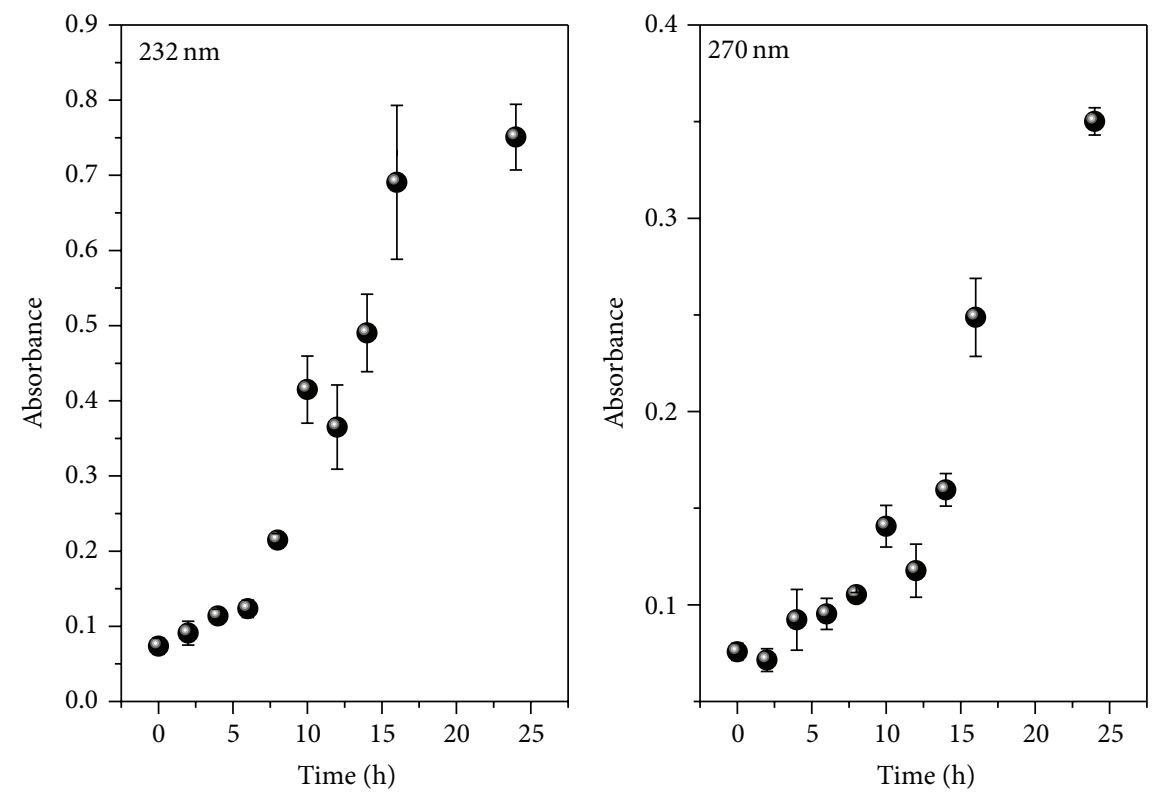

FIgURE 3: Baru oil absorbance at 232 and $270 \mathrm{~nm}$ as a function of the heating time. The oil samples were heated at $110^{\circ} \mathrm{C}$.

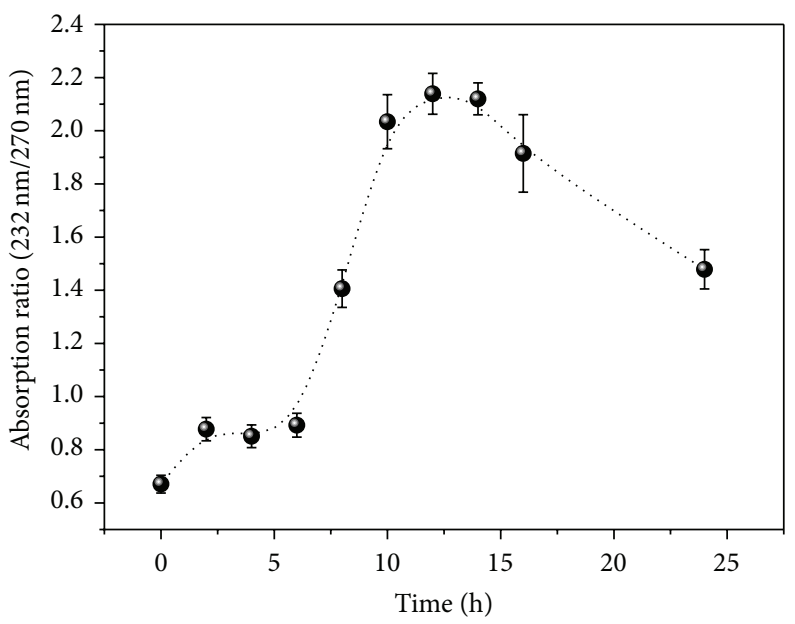

FIgURE 4: Baru oil absorption ratio at 232 to $270 \mathrm{~nm}$ as a function of the heating time.

However, a fluorescence increase at around $500 \mathrm{~nm}$ during the first 8 hours was detected, as also shown in Figure 7, in which this emission is a contribution of the oxidation products [23]. As recently demonstrated by Magalhães et al., conjugated tetraenes were identified in the degraded samples, presenting a fluorescent emission in the $350-500 \mathrm{~nm}$ range, in which the conjugated tetraenes molecules were formed from the degradation of unsaturated molecules [24].

In summary, our results indicate that carotenoid and chlorophyll degradation in the oil can be used as an indicator to monitor the overall oil degradation, by both fluorescence and absorption analyses. Therefore, the results showed that fluorescence spectroscopy has great potential to be accurately applied for monitoring the oxidative stability of vegetable oils by using a low cost and portable device.

\section{Conclusion}

In conclusion, we investigated the thermal stability of Baru oil by analyzing the optical features of the samples. The results strongly suggest that carotenoids and chlorophylls were almost completely degraded during the thermal treatment and that primary (conjugated dienes) and secondary (diketones and unsaturated ketones) oxidation products were generated during the thermooxidation process. In summary, our data showed that fluorescence as well as absorption can be potentially used to detect oxidative degradation of this oil, by monitoring the carotenoid and chlorophyll degradation. In general, as it is possible to obtain a rapid, precise, and noninvasive analysis using a portable device by optical methods, our results indicate that fluorescence and 


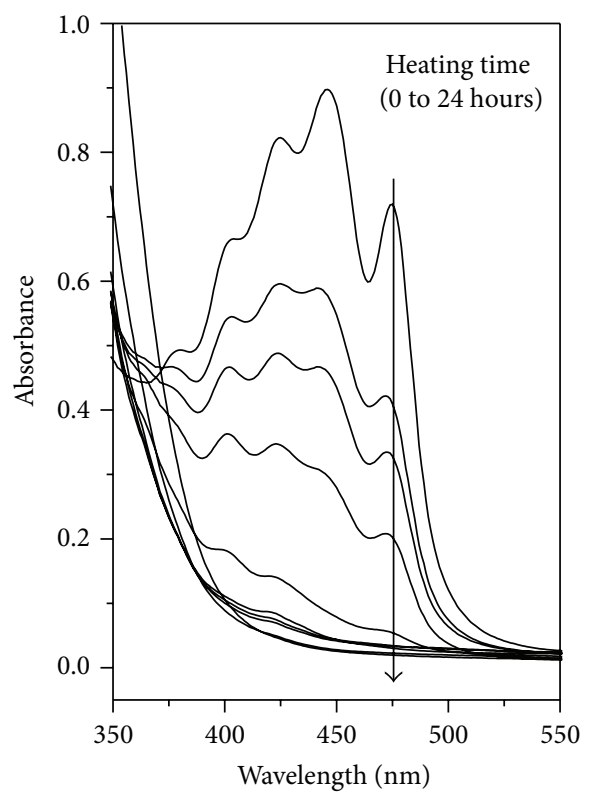

(a)

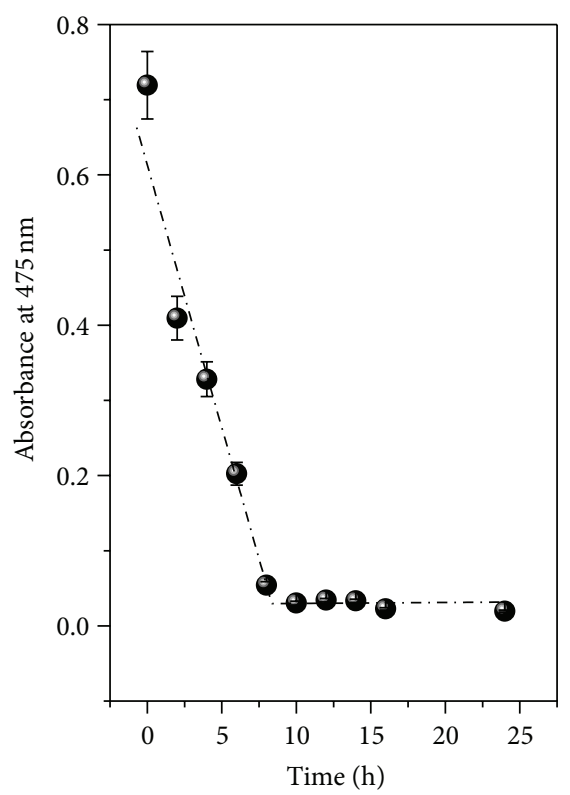

(b)

Figure 5: (a) Decrease in absorption over the degradation period. (b) Absorbance at $475 \mathrm{~nm}$ as a function of the heating time.

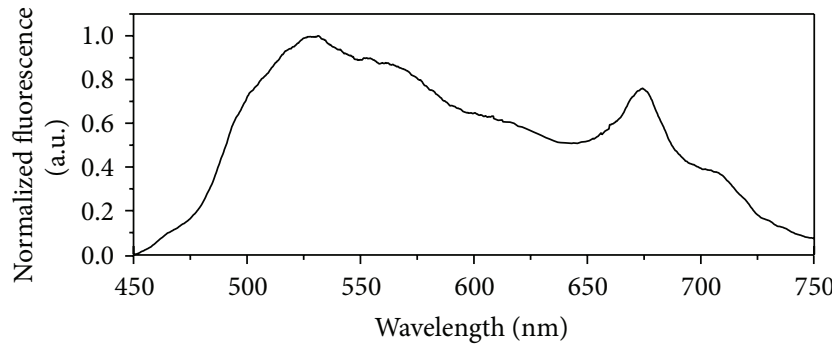

— Baru oil

(a)

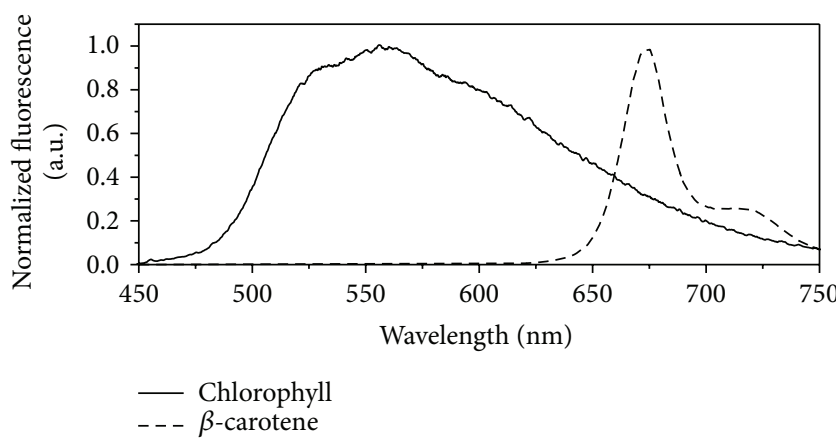

(b)

FIGURE 6: Fluorescence spectrum of (a) Baru oil and (b) $\beta$-carotene and chlorophyll.

absorption spectroscopy can be applied to develop alternative methods for assessing oil quality. However, aiming to develop a robust method for oil analysis, it is needed to evaluate different oils produced from different raw materials as well as

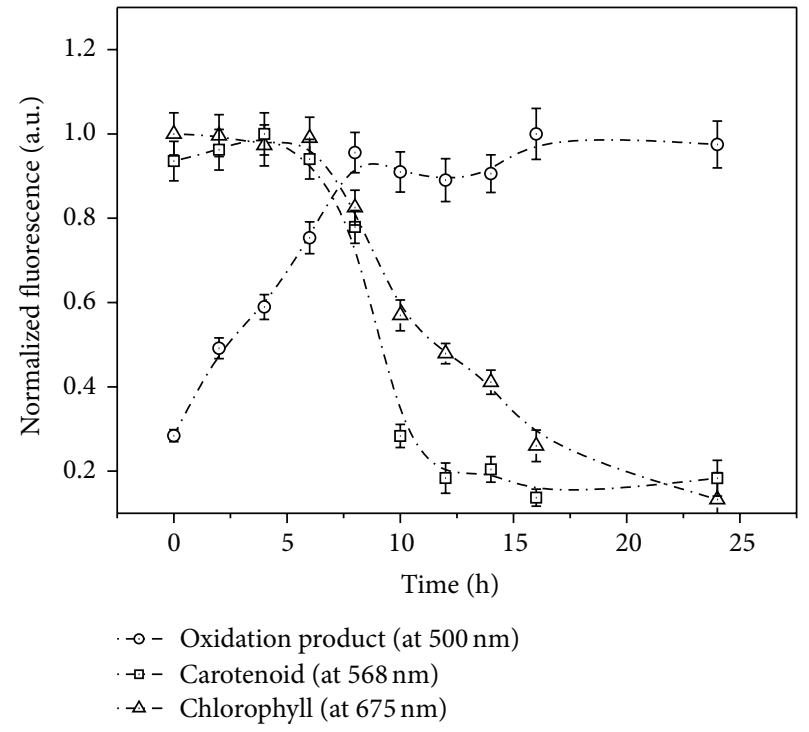

FIGURE 7: Fluorescence intensity at 500, 568, and $675 \mathrm{~nm}$, when excited at $405 \mathrm{~nm}$, as a function of the heating time.

characterize the oil degradation when exposed to the different environments (e.g., light, heat, metal-containing).

\section{Conflict of Interests}

The authors declare that there is no conflict of interests regarding the publication of this paper. 


\section{Acknowledgments}

The authors are grateful for financial support from $\mathrm{CNPq}$, CAPES, and FUNDECT. The authors also acknowledge the support provided by the National Institute of Science and Technology of Optics and Photonics (INOF).

\section{References}

[1] H. Lorenzi, Árvores brasileiras: manual de identificação e cultivo de plantas arbóreas nativas do Brasil, Plantarum, Nova Odessa, Brazil, 2nd edition, 1992.

[2] S. M. Sano, M. A. Brito, and J. F. Ribeiro, Frutas Nativas da Região Centro-Oeste do Brasil, Embrapa Recursos Genéticos e Biotecnologia, Brasília, Brazil, 2006.

[3] E. Takemoto, I. A. Okada, M. L. Garbelotti, M. Tavares, and S. Aued-Pimentel, "Composição química da semente e do óleo de baru (Dipteryx alata Vog.) nativo do município de Pirenópolis, Estado de Goiás," Revista do Instituto Adolfo Lutz, vol. 60, no. 2, pp. 113-117, 2001.

[4] D. C. Fernandes, J. B. Freitas, L. P. Czeder, and M. M. V. Naves, "Nutritional composition and protein value of the baru (Dipteryx alata Vog.) almond from the Brazilian Savanna," Journal of the Science of Food and Agriculture, vol. 90, no. 10, pp. 1650-1655, 2010.

[5] C. C. Garcia, P. I. B. M. Franco, T. O. Zuppa, N. R. A. Filho, and M. I. G. Leles, "Thermal stability studies of some cerrado plant oils," Journal of Thermal Analysis and Calorimetry, vol. 87, no. 3 , pp. 645-648, 2007.

[6] A. C. F. Batista, H. S. Rodrigues, N. R. Pereira, M. G. HernandezTorrones, A. T. Vieirra, and M. F. Oliveira, "Use of baru oil (Dipteryx alata Vog.) to produce biodiesel and study of the physical and chemical characteristics of biodiesel/petroleum diesel fuel blends," Chemistry and Technology of Fuels and Oils, vol. 48, no. 1, pp. 13-16, 2012.

[7] R. Dinkov, G. Hristov, D. Stratiev, and V. B. Aldayri, "Effect of commercially available antioxidants over biodiesel/diesel blends stability," Fuel, vol. 88, no. 4, pp. 732-737, 2009.

[8] R. O. Dunn, "Effect of antioxidants on the oxidative stability of methyl soyate (biodiesel)," Fuel Processing Technology, vol. 86, pp. 1071-1085, 2005.

[9] M. B. Dantas, A. R. Albuquerque, A. K. Barros et al., "Evaluation of the oxidative stability of corn biodiesel," Fuel, vol. 90, no. 2, pp. 773-778, 2011.

[10] M. Mittelbach and S. Gangl, "Long storage stability of biodiesel made from rapeseed and used frying oil," Journal of the American Oil Chemists' Society, vol. 78, no. 6, pp. 573-577, 2001.

[11] G. Knothe and R. O. Dunn, "Dependence of oil stability index of fatty compounds on their structure and concentration and presence of metals," Journal of the American Oil Chemists' Society, vol. 80, no. 10, pp. 1021-1026, 2003.

[12] R. Cheikhousman, M. Zude, D. J.-R. Bouveresse, C. L. Léger, D. N. Rutledge, and I. Birlouez-Aragon, "Fluorescence spectroscopy for monitoring deterioration of extra virgin olive oil during heating," Analytical and Bioanalytical Chemistry, vol. 382, no. 6, pp. 1438-1443, 2005.

[13] M. D. Scherer, S. L. Oliveira, S. M. Lima, L. H. C. Andrade, and A. R. L. Caires, "Determination of the biodiesel content in diesel/biodiesel blends: a method based on fluorescence spectroscopy," Journal of Fluorescence, vol. 21, no. 3, pp. 10271031, 2011.
[14] A. R. L. Caires, V. S. Lima, and S. L. Oliveira, "Quantification of biodiesel content in diesel/biodiesel blends by fluorescence spectroscopy: evaluation of the dependence on biodiesel feedstock," Renewable Energy, vol. 46, pp. 137-140, 2012.

[15] T. A. Chimenez, K. F. Magalhães, A. R. L. Caires, and S. L. Oliveira, "Fluorescence as an analytical tool for assessing the conversion of oil into biodiesel," Journal of Fluorescence, vol. 22, no. 4, pp. 1177-1182, 2012.

[16] American Oil Chemists' Society, Official Methods and Recommended Practices of the American Oil Chemists' Society, American Oil Chemists' Society, Champaign, Ill, USA, 5th edition, 2009.

[17] M. L. S. Albuquerque, I. Guedes, P. Alcantra Jr. et al., "Characterization of Buriti (Mauritia flexuosa L.) oil by absorption and emission spectroscopies," Journal of the Brazilian Chemical Society, vol. 16, no. 6, pp. 1113-1117, 2005.

[18] B. Schoefs, "Chlorophyll and carotenoid analysis in food products. Properties of the pigments and methods of analysis," Trends in Food Science and Technology, vol. 13, no. 11, pp. 361371, 2002.

[19] I. V. Ermakov and W. Gellermann, "Optical detection methods for carotenoids in human skin," Archives of Biochemistry and Biophysics, 2015.

[20] S. Krawczyk and R. Luchowski, "Vibronic structure and coupling of higher excited electronic states in carotenoids," Chemical Physics Letters, vol. 564, pp. 83-87, 2013.

[21] L. K. Henry, G. L. Catignani, and S. J. Schwartz, "Oxidative degradation kinetics of lycopene, lutein, and 9-cis and all-trans $\beta$-carotene," Journal of the American Oil Chemists' Society, vol. 75, no. 7, pp. 823-829, 1998.

[22] C. Qian, E. A. Decker, H. Xiao, and D. J. McClements, "Inhibition of $\beta$-carotene degradation in oil-in-water nanoemulsions: influence of oil-soluble and water-soluble antioxidants," Food Chemistry, vol. 135, no. 3, pp. 1036-1043, 2012.

[23] F. Guimet, J. Ferré, R. Boqué, and F. X. Rius, "Application of unfold principal component analysis and parallel factor analysis to the exploratory analysis of olive oils by means of excitationemission matrix fluorescence spectroscopy," Analytica Chimica Acta, vol. 515, no. 1, pp. 75-85, 2004.

[24] K. F. Magalhães, A. R. L. Caires, M. S. Silva, G. B. Alcantara, and S. L. Oliveira, "Endogenous fluorescence of biodiesel and products thereof: investigation of the molecules responsible for this effect," Fuel, vol. 119, pp. 120-128, 2014. 

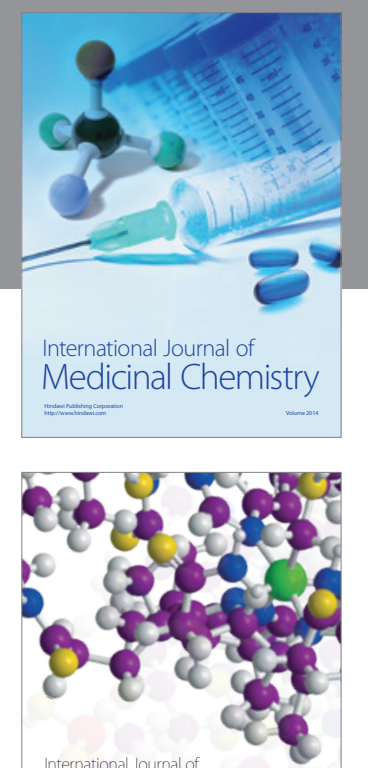

\section{Carbohydrate} Chemistry

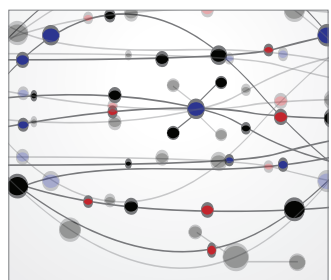

The Scientific World Journal
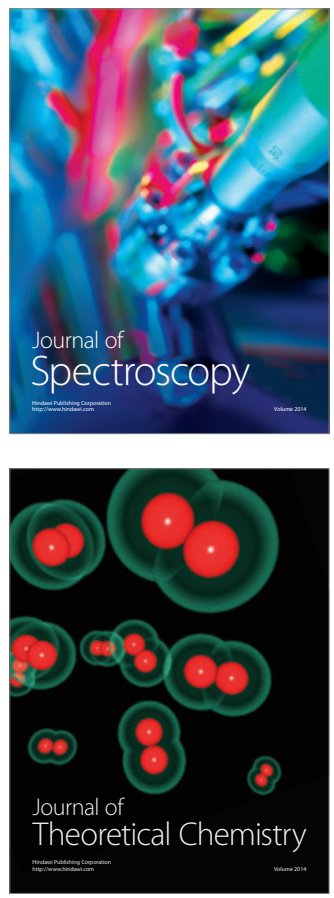
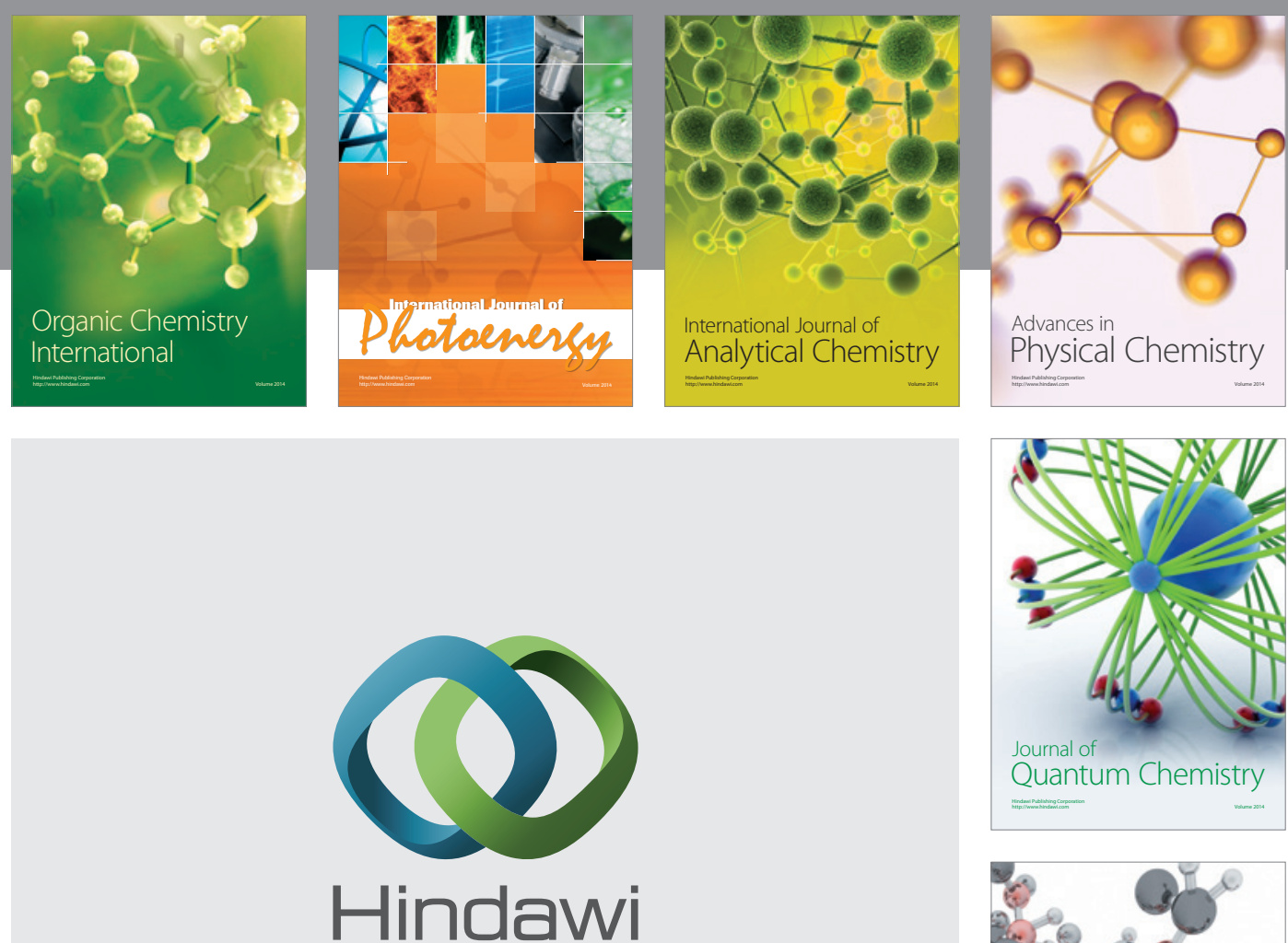

Submit your manuscripts at

http://www.hindawi.com

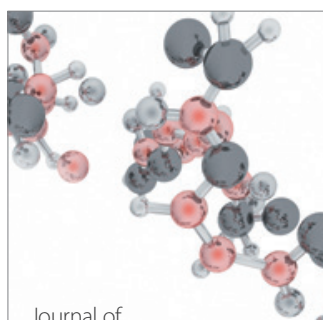

Analytical Methods

in Chemistry

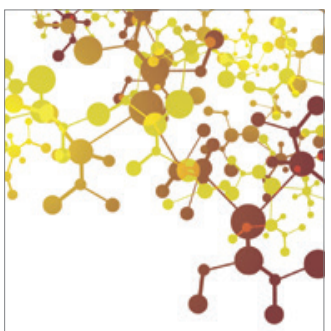

Journal of

Applied Chemistry

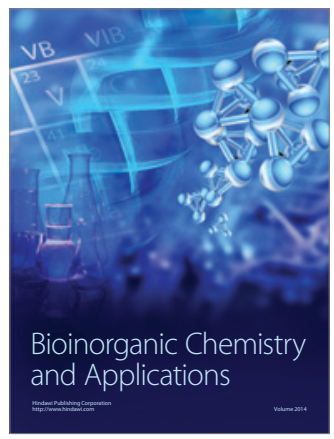

Inorganic Chemistry
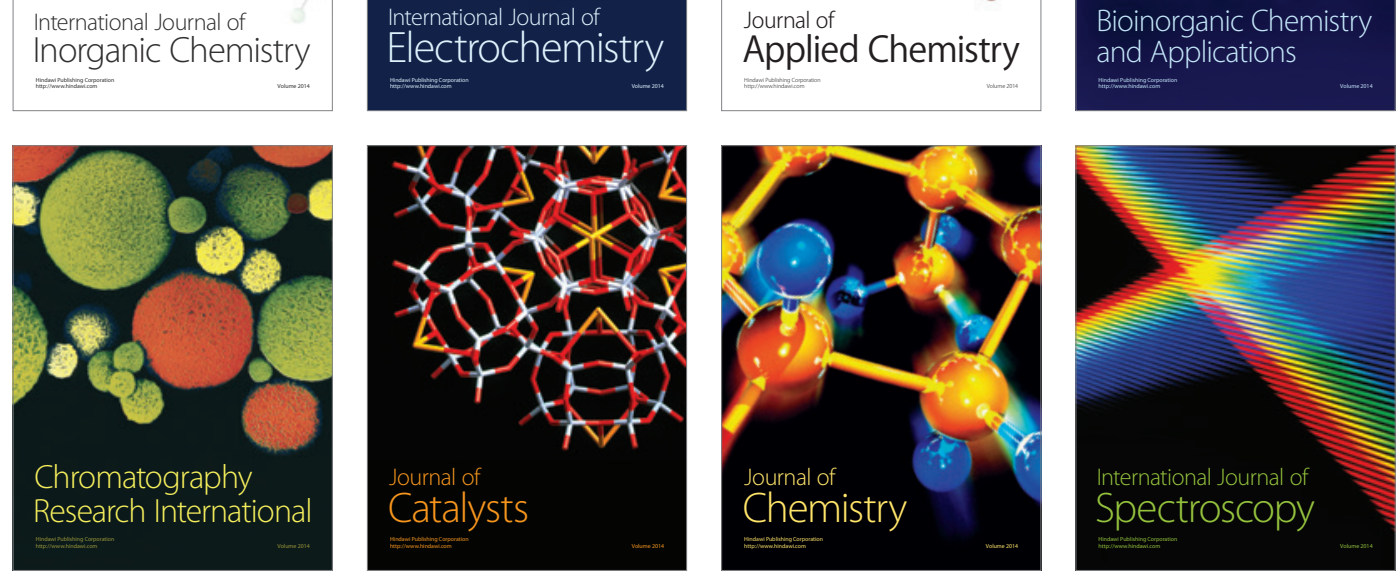